\title{
RESEARCH INTO PRACTICE
}

\section{New guidelines on recurrent wheeze in preschool children: implications for primary care}

\begin{abstract}
*Paul Brand
Consultant Paediatric Respiratory Chest

Physician, Princess Amalia Children's Clinic and Professor of Clinical Medical Education, UMCG Postgraduate School of Medicine; University Medical Centre, Groningen, The Netherlands

\section{${ }^{*}$ Correspondence:}

Professor Paul LP Brand, Isala Klinieken, Princess Amalia Children's Clinic, PO Box 10400, Zwolle, 8000 GK, Netherlands

Tel: +31384245050

Fax: +31384247660

E-mail: p.l.p.brand@isala.nl

\section{2nd October 2008}

(c) 2008 General Practice Airways Group. All rights reserved
\end{abstract}

Keyw ords asthma, guideline, paediatrics, wheeze, preschool, diagnosis, management

\section{Introduction}

Two years ago, Bush described the challenges of diagnosing asthma in preschool children in this journal. ${ }^{1}$ Both in his paper, and in the accompanying editorial, ${ }^{2}$ the lack of "good, validated data" on management of this very common disorder was lamented. Furthermore, asthma guidelines are not very helpful; either they do not discuss preschool wheezing at all, or they discuss it very briefly.3.4

The lack of evidence-based guidelines for the diagnosis and management of preschool wheeze prompted the European Respiratory Society to institute a Task Force to develop such guidelines. The Task Force's Report has recently been published. ${ }^{5}$ This 'Research into Practice' paper describes the report's main recommendations, and the implications for managing preschool wheezing in primary care.

\section{Methodology}

In contrast to earlier consensus reports, the Task Force applied SIGN methodology to retrieve and appraise relevant research articles on preschool wheeze. Details are discussed in the Report. ${ }^{5}$ The quality of evidence and grading of recommendations was performed according to the GRADE system. ${ }^{7}$ The Task Force's activities were supported by a grant from the European Respiratory Society. Any sponsorship or support from pharmaceutical companies was deliberately avoided.

\section{Definitions}

Until this report, ${ }^{5}$ no attempt had been made to standardise the terminology of preschool wheezing. As a result, definitions used have been confusing. The Task Force recommends that clinicians use a descriptive approach based on symptoms alone, and that the term "asthma" is avoided - because airway inflammation, one of the hallmarks of asthma in older children and adults, ${ }^{3,4}$ has been poorly studied in preschool children, and may even be absent in this age range. ${ }^{1,8}$

The main distinction to be made is based on the temporal pattern of wheeze (see Table 1). Episodic viral wheeze should be separated from multiple trigger wheeze because this has therapeutic consequences.

\section{Table 1. Definitions of wheeze.}

Temporal pattern of wheeze: useful in clinical practice

\begin{tabular}{ll}
\hline $\begin{array}{l}\text { Episodic (viral) wheeze } \\
\text { Multiple trigger wheeze }\end{array}$ & $\begin{array}{l}\text { Wheezing during discrete episodes, often in association with clinical evidence of a viral cold; no wheeze } \\
\text { between episodes } \\
\text { Wheezing that shows discrete exacerbations, but also symptoms between episodes }\end{array}$ \\
\hline Duration of wheeze: only useful in population studies, not in clinical practice \\
\hline Transient wheeze & $\begin{array}{l}\text { Symptoms that commenced before the age of } 3 \text { years and are found (retrospectively) to have disappeared by the } \\
\text { age of } 6 \text { years (transient wheeze may be episodic viral wheeze or multiple trigger wheeze) }\end{array}$ \\
Persistent wheeze & $\begin{array}{l}\text { Symptoms that are found (retrospectively) to have continued until the age of } 6 \text { years and older (persistent wheeze } \\
\text { may be episodic viral wheeze or multiple trigger wheeze) }\end{array}$ \\
Late onset wheeze & Wheeze that starts after the age of 3 years (late onset wheeze may be episodic viral wheeze or multiple trigger wheeze)
\end{tabular}


Based on the outcome of wheeze over time, birth cohort studies distinguish transient and persistent wheeze (Table 1). ${ }^{9}$ This distinction can only be made retrospectively at the age of 6 years; therefore, it has no clinical usefulness in managing wheeze in preschool children. Although many clinicians believe that episodic viral wheeze is usually transient, and multiple trigger wheeze is commonly persistent over time, this is not supported by the evidence. The distinction between different wheezing phenotypes in early childhood is based on statistically significant differences in patient characteristics between groups. Both research evidence and clinical experience show that there is considerable overlap between these "phenotypes", that children may change their phenotype over time, and that a clear distinction between episodic and multiple trigger wheeze is, therefore, often impossible. This is not surprising if one considers the multitude of genetic and environmental factors implicated in the pathogenesis of wheeze in general, ${ }^{10}$ and of preschool wheeze in particular. ${ }^{1}$ Attempts have been made to predict which preschool wheezing children will continue to wheeze after the age of 6 years and develop asthma. ${ }^{11,12}$ Although the "asthma predictive index" may help to identify a group of children more likely to respond to inhaled corticosteroids, ${ }^{13}$ the predictive value of such an index in clinical management of individual patients is limited (i.e. the sensitivity to predict "asthma" is only $55-60 \%$, for example, and the specificity $80 \%$ ).

\section{Assessment}

Given the high prevalence of preschool wheezing, the lack of studies on the assessment and differential diagnosis of this disorder is striking. All recommendations in this area were based on very low levels of evidence, and they are in line with Bush's advice: ${ }^{1}$

- The pattern and triggers of wheeze, personal and family history of atopy and asthma, and exposure to tobacco smoke should be assessed by taking a history from the parents

- Parentally-reported wheeze should be confirmed by a health care professional whenever possible because parents vary considerably in their understanding and use of the term "wheeze"

- Isolated cough without confirmed wheeze (or other symptoms) is a common, self-limiting symptom which does not justify investigations or treatment

- Specific diagnostic tests are only indicated in the presence of unusual features (e.g., poor growth, unusually severe or protracted wheezing episodes); patients should be referred to a paediatrician for such investigations.

\section{Treatment}

The Task Force's main recommendations regarding treatment are summarised in Table 2. In all children with recurrent troublesome wheeze, reduction of exposure to tobacco smoke and parental education are clearly useful. There is evidence to suggest that montelukast is the preferred treatment for episodic viral wheeze

Table 2. Treatment of preschool wheeze.

Non-pharmacological therapy
Reduce exposure to tobacco smoke
Allergen avoidance
Patient and parent education

Pharmacological therapy: acute episode

Inhaled short-acting $\beta_{2}$-agonist

by metered dose inhaler/spacer combination

Systemic corticosteroids
- More effective than placebo

- More effective than nebulized treatment ${ }^{17}$

- Only useful in children with acute severe wheeze in hospital; number needed to treat (NNT) to avoid 1 hospitalisation is $3^{18}$

- No evidence of usefulness in primary care ${ }^{19}$

- No evidence of usefulness in children $<1$ year of age ${ }^{20}$

\begin{tabular}{|c|c|}
\hline \multicolumn{2}{|c|}{ Pharmacological therapy: episodic viral wheeze } \\
\hline Montelukast & $\begin{array}{ll}\text { - } & \text { Reduces virus-induced wheezing episodes (NNT 12) })^{21} \\
\text { - } & \text { Can be started at first sign of viral coldd } \\
\text { - } & \text { Has not been studied in primary care }\end{array}$ \\
\hline Inhaled corticosteroids & $\begin{array}{l}\text { - Few trials available; small number of subjects } \\
\text { - No effect of maintenance treatment shown on number or severity of episodes }{ }^{23}\end{array}$ \\
\hline \multicolumn{2}{|c|}{ Pharmacological therapy: multiple trigger wheeze } \\
\hline Inhaled corticosteroids & $\begin{array}{l}\text { - Effective in maintenance treatment: improves symptoms, exacerbations, and } \\
\text { hyperresponsiveness }{ }^{23} \\
\text { - } \quad \text { Effect smaller in younger children; no effect demonstrated in infants }<1 \text { year of age } \\
\text { - More effective than montelukast }{ }^{24}\end{array}$ \\
\hline Montelukast & $\begin{array}{l}\text { - } \quad \text { Reduces symptoms and exacerbations } s^{25} \\
\text { - } \quad \text { Less effective than inhaled corticosteroids } s^{24}\end{array}$ \\
\hline
\end{tabular}


whilst inhaled corticosteroids are the therapy of choice in multiple trigger wheeze (see Table 2). Some remarks must be made, however;

- First and foremost, it is often impossible to distinguish episodic viral wheeze and multiple trigger wheeze. Studies have been performed in polarised groups which do not reflect clinical practice.

- Almost all studies have been performed in hospital-based populations. The very few studies on effects of inhaled corticosteroids in preschool children in primary care have shown no effect; ${ }^{14}$ montelukast has not been studied in primary care

- Montelukast is not licensed for use in children under 2 years of age in many countries

- Age is an important effect modifier: the younger the child, the poorer the response to any treatment

- Wheeze in preschool children, irrespective of its pattern or phenotype, tends to resolve spontaneously over time. This is particularly true in primary care

- Maintenance treatment of preschool wheeze does not affect long-term outcome or persistence of wheeze ${ }^{1}$

\section{Implications for primary care}

A preschool child presenting with recurrent troublesome wheeze requires careful assessment by history taking; parental report of wheeze should be confirmed by the primary care physician whenever possible. ${ }^{1}$ If other underlying conditions are suspected, the child should be referred to specialist paediatric care. Distinguishing between episodic viral wheeze and multiplectrigger wheeze is useful but not always possible. In all of these children, parents should be counselled on the avoidance of exposure to tobacco smoke and on the favourable natural history of most preschool wheezing syndromes. Inhaled short-acting $\beta_{2}$-agonists by metered dose inhaler/spacer combination should be prescribed, and parents should be trained how to use this. In children with truly troublesome symptoms, maintenance treatment should be considered. In multiple trigger wheeze, inhaled corticosteroids are the first choice, whilst montelukast may be considered for treating episodic viral wheeze. Because distinction between these phenotypes is not always possible, either treatment can be provided on a trial basis. The threshold to withdraw treatment once symptoms have resolved should be low.

\section{Conflict of interest declaration}

The author has received fees for lecturing and consultancy from GSK, AZ, Nycomed, and MSD.

\section{References}

1. Bush A. Diagnosis of asthma in children under five. Prim Care Resp J 2007; 16:7-15. doi:10.3132/pcrj.2007.00001

2. Pedersen S. Preschool asthma - not so easy to diagnose. Prim Care Resp J 2007; 16:4-6. doi:10.3132/pcrj.2007.00011

3. National Heart Lung and Blood Institute, National Asthma Education and Prevention Program. Expert Panel Report 3: Guidelines for the diagnosis and management of asthma. Bethesda, MD, USA, National Heart, Lung and Blood
Institute 2007

4. British Thoracic Society, Scottish Intercollegiate Guidelines Network: British guideline on the management of asthma. Thorax 2003;58(Suppl.1):i1-i94.

5. Brand PL, Baraldi E, Bisgaard H, et al. Definition, assessment and treatment of wheezing disorders in preschool children: an evidence-based approach. Eur Respir J 2008;32:1096-110.

6. Bacharier LB, Boner A, Carlsen $\mathrm{KH}$, et al. Diagnosis and treatment of asthma in childhood: a PRACTALL consensus report. Allergy 2008;63:5-34.

7. Atkins D, Best D, Briss PA, et al. Grading quality of evidence and strength of recommendation. BMJ 2004;328:1490-4.

8. Saglani S, Malmstrom K, Pelkonen AS, et al. Airway remodeling and inflammation in symptomatic infants with reversible airflow obstruction. Am J Respir Crit Care Med 2005;171:722-7.

9. Martinez FD, Wright AL, Taussig LM, Holberg CJ, Halonen M, Morgan WJ, Group Health Medical Associates. Asthma and wheezing in the first six years of life. N Engl J Med 1995;332:133-8.

10. Anderson GP. Endotyping asthma: new insights into key pathogenic mechanisms in a complex, heterogeneous disease. Lancet 2008;372:1107-19.

11. Castro-Rodríguez JA, Holberg CJ, Wright AL, Martinez FD. A clinical index to define risk of asthma in young children with recurrent wheezing. Am J Respir Crit Care Med 2000;162:1403-06.

12. Frank PI, Morris JA, Hazell ML, Lìnehan MF, Frank TL. Long term prognosis in preschool children with wheeze: longitudinal postal questionnaire study 1993 2004. BMJ 2008;336:1423-6.

13. Guilbert TW, Morgan WJ, Zeiger RS, et al. Long-term inhaled corticosteroids in preschool children at high risk for asthma. N Engl J Med 2006;354:1985-97.

14. Schokker S, Kooi EM, de Vries TW, et al. Inhaled corticosteroids for recurrent respiratory symptoms in preschool children: randomized controlled trial. Pulm Pharmacol Ther 2008; 21:88-97

15. Strachan DP, Cook DG. Parental smoking and lower respiratory illness in infancy and early childhood. Thorax 1997;52:905-14

16. Wolf FM, Guevara JP, Grum CM, Clark NM, Cates CJ. Educational interventions for asthma in children. Cochrane Database Syst Rev 2002;(4):CD000326.

17. Castro-Rodriguez JA, Rodrigo GJ. $\beta$-agonists through metered-dose inhaler with valved holding chamber versus nebulizer for acute exacerbation of wheezing or asthma in children under 5 years of age: a systematic review with meta-analysis. J Pediatr 2004;145:172-7.

18. Smith M, lqbal S, Elliott TM, Everard M, Rowe BH. Corticosteroids for hospitalised children with acute asthma. Cochrane Database Syst Rev 2003;(2):CD002886.

19. Oommen A, Lambert PC, Grigg J. Efficacy of a short course of parent-initiated oral prednisolone for viral wheeze in children aged 1-5 years: randomised controlled trial. Lancet 2003;362:1433-8.

20. Webb MSC, Henry RL, Milner AD. Oral corticosteroids for wheezing attacks under 18 months. Arch Dis Child 1986;61:15-19

21. Bisgaard H, Zielen S, Garcia-Garcia ML, Johnston SL, Gilles L, Menten J, Tozzi CA, Polos P. Montelukast reduces asthma exacerbations in 2- to 5-year-old children with intermittent asthma. Am J Respir Crit Care Med 2005;171:315-22.

22. Robertson CF, Price D, Henry R, et al. Short-course montelukast for intermittent asthma in children: a randomized controlled trial. Am J Respir Crit Care Med 2007:175:323-9.

23. Kaditis AG, Winnie G, Syrogiannopoulos GA. Anti-inflammatory pharmacotherapy for wheezing in preschool children. Pediatr Pulmonol 2007; 42:407-20.

24. Szefler SJ, Baker JW, Uryniak T, Goldman M, Silkoff PE. Comparative study of budesonide inhalation suspension and montelukast in young children with mild persistent asthma. J Allergy Clin Immunol 2007;120:1043-50.

25. Knorr B, Franchi LM, Bisgaard $\mathrm{H}$, et al. Montelukast, a leukotriene receptor antagonist, for the treatment of persistent asthma in children aged 2 to 5 years. Pediatrics 2001;108(3):e48. 